\title{
Barnyardgrass with Multiple Resistance to Synthetic Auxin, ALS AND ACCASE INHIBITORS ${ }^{1}$
}

\author{
Capim-Arroz com Resistência Múltipla a Auxina Sintética, Inibidores de ALS e ACCase
}

\author{
EBERHARDT, D.S. ${ }^{2}$, OLIVEIRA NETO, A.M. ${ }^{3}$, NOLDIN, J.A. ${ }^{2}$, and VANTI, R.M. ${ }^{4}$
}

\begin{abstract}
The objective of this research was to confirm the resistance of a barnyardgrass biotype (Echinochloa crus-galli) to herbicides quinclorac (synthetic auxin), penoxsulam (ALS inhibitor) and cyhalofop-butyl (ACCase inhibitor). Two experiments were carried out in a greenhouse located in Itajaí, State of Santa Catarina, Brazil. One experiment evaluating the biotype ECH 18 (known as susceptible) and one with the ECH 141 biotype (suspected to be multiple resistant). The experimental design used was completely randomized, in a $4 \times 7$ factorial arrangement with four replications. The first factor was the herbicide: cyhalofopbutyl $\left(\right.$ Clincher $\left.^{\circledR}\right)$, penoxsulam $\left(\right.$ Ricer $\left.^{\circledR}\right)$, quinclorac $\left(\right.$ Facet $\left.^{\circledR}\right)$ and propanil $\left(\right.$ Grassaid $\left.^{\circledR}\right)$ and the second factor consisting of seven rates of each herbicide $(0.00 ; 0.25 ; 0.50 ; 1 ; 2 ; 4$ and 8 times the label rate). The evaluations of percentage of control, plant density per pot and dry mass of shoots were performed 35 days after treatments. The rates to control $50 \%$ and $80 \%$ and the dose to provide $50 \%$ and $80 \%$ of the weed biomass accumulation and the resistance factor were estimated based on data analysis. The initial hypothesis was confirmed; the biotype ECH 141 presented multiple resistance (synthetic auxin, ALS and ACCase inhibitor). However, the herbicide propanil controlled biotype ECH 141 adequate.
\end{abstract}

Keywords: Paddy rice, Echinochloa crus-galli, chemical control, herbicide resistance.

\begin{abstract}
RESUMO - Este estudo teve como objetivo confirmar a resistência múltipla de um biótipo de capimarroz (Echinochloa crus-galli) aos herbicidas auxinicos (quinclorac), inibidores da ALS (penoxsulam) e ACCase (cyhalofop-butyl). Foram conduzidos dois experimentos em casa de vegetação localizada no municipio de Itajai/SC: um com o biótipo ECH 18 (sabidamente suscetivel) e outro com o biótipo ECH 141 (com suspeita de resistência múltipla). O delineamento experimental utilizado foi o inteiramente casualizado (DIC), organizado em arranjo fatorial $4 \times 7$, com quatro repetições. O primeiro fator avaliado foram os herbicidas: cyhalofop-butyl, penoxsulam, quinclorac e propanil (Clincher ${ }^{\circledR}$, Ricer $^{\circledR}$, Facet $^{\mathbb{B}}$ e Grassaid $^{\circledR}$, respectivamente). O segundo fator consistiu de sete doses de cada herbicida $(0,00,0,25,0,50,1,00,2,00,4,00$ e 8,00 vezes a dose de registro). Aos 35 dias após a aplicação dos tratamentos, foram realizadas as avaliações de porcentagem de controle, densidade de plantas por vaso e massa seca da parte aérea. Após a análise dos dados, estimou-se a dose para proporcionar controle de 50\% e 80\%, a dose para proporcionar redução de 50\% e 80\% no acúmulo de biomassa e ofator de resistência. A hipótese inicial foi confirmada, pois o biótipo ECH 141 apresentou resistência múltipla aos herbicidas quinclorac (auxina sintética), penoxsulam (inibidor da ALS) e cyhalofop-butyl (inibidor de ACCase). Contudo, o herbicida propanil o controlou com eficiência.
\end{abstract}

Palavras-chave: arroz irrigado, controle químico, Echinochloa crus-galli, resistência a herbicidas.

Recebido para publicação em 17.9.2015 e aprovado em 27.11.2015.

2 Epagri, Estação Experimental de Itajaí-SC, Brazil, <noldin@epagri.sc.gov.br $>$ e $<$ dsavioe@gmail.com>; ${ }^{3}$ Universidade Federal de Pelotas, Pelotas-RS; ${ }^{4}$ Agroas Agronomia Ltda. Tubarão-SC, Brazil. 


\section{INTRODUCTION}

The genus Echinochloa (Poaceae) contains several species infesting rice crops in southern of Brazil (Andres \& Machado, 2004), among which Echinochloa crus-galli (barnyardgrass), native to Europe and Asia, highlights as the main specie (Talbert \& Burgos, 2007). The occurrence of in-field natural hybrids results in a high level of polymorphism through the genus, leading botanists to use the term "Echinochloa complex" to encompass these species (Kissmann \& Groth, 1997). Concerning to the field management, barnyardgrass species present different sensitivity levels to herbicides in general, and the most sensitive species are the E. crus-galli, E. phyllopogon and E. oryzoides (Damalas et al., 2008).

Resistant plants have inherited ability to survive and reproduce after exposure to a dose of herbicide normally lethal to the natural population (Gazziero et al., 2008; Inoue \& Oliveira Jr, 2011). Weed biotypes with multiple resistance, i.e., resistant to herbicides with different mechanisms of action, have greatly hindered weed control (Moura et al., 2015), constituting a major problem faced by farmers in paddy rice fields.

Selection of resistant biotypes is common in weeds population due to the wide genetic variability, which allows the adaptation and survival in different environmental conditions (Christoffoleti, 2008). Two main factors further aggravate the selection pressure in Santa Catarina rice fields: a) lack of crop rotation; and, b) repeated use of herbicides with the same mechanism of action. This situation became worse in recent years, especially because the selection pressure is on populations that are already resistant to some herbicides. Five resistant species have been already identified, two with multiple resistance (Heap, 2015).

The Arkansas State (USA) situation exemplifies this process, since the repeated use of propanil led to resistant barnyardgrass selection in 1989. The measure adopted to control these biotypes was the replacement of propanil by quinclorac, however, barnyardgrass with resistance to propanil and quinclorac was confirmed in 1999 (Burgos \& Talbert, 2007). This situation was similar in Brazil, where firstly was identified barnyardgrass biotype with resistance to synthetic auxin (quinclorac), and then occurred a selection of biotypes with resistance to synthetic auxin and ALS inhibitors (Heap, 2015). There were also reported cases of barnyardgrass with multiple resistances to herbicides in rice in Italy, Philippines, South Korea, Thailand and Turkey (Heap, 2015). These global cases of resistant barnyardgrass to herbicides with different mechanisms of action confirmed the ability to develop resistance mechanisms (Talbert \& Burgos, 2007).

Areas with barnyardgrass biotypes with resistance to synthetic auxin and ALS inhibitors are increasing in Santa Catarina. An alternative control used by some rice farmers is the application of cyhalofop-butyl. The first suspicion of multiple resistance involving three mechanisms of action rose with the intensification of ACCase inhibitor applications. A farmer reported the lack of control of barnyardgrass after applying the herbicide cyhalofop-butyl in the 2014/ 15 crop season in a field with population resistant to quinclorac, bispyribac-sodium, penoxsulam and imazapic + imazethapyr.

Therefore, dose-response experiments were conducted to confirm or disprove the multiple resistances of a barnyardgrass biotype (E. crus-galli) involving synthetic auxinic (quinclorac), ALS (penoxsulam) and ACCase (cyhalofop-butyl) inhibitor herbicides.

\section{MATERIAL AND METHODS}

Two experiments were conducted in a greenhouse located in Itajaí, Santa Catarina, Brazil (2657'06,34” S, 4845’41,33” W), during December 2014 and January 2015.

The experiments were conducted at the same time, with the same methodology and treatments, differing only by the barnyardgrass biotypes. One experiment was conducted with a susceptible biotype (ECH 18), using seeds collected in Itajai, SC, prior to the herbicide resistance confirmation, which were maintained in cold storage. The other experiment was conducted with seeds of the 
barnyardgrass biotype (ECH 141) from a commercial area of irrigated rice, located in Tubarão, SC with suspicious to be resistant to synthetic auxin, ALS and ACCase inhibitors.

Preliminaries tests was conducted to verify a possible multiple resistance, which consisted of applications of (imazapyr+ imazapic) $\left(147+49\right.$ g a.i. ha $\left.{ }^{-1}\right)$ (Kifix $\left.{ }^{\circledR}\right)$, penoxsulam (48 g a.i. ha-1), $\left(\right.$ Ricer $\left.^{\circledR}\right)$, quinclorac (500 g a.i. ha-1) $\left(\right.$ Facet $\left.^{\circledR}\right)$, cyhalofop-butyl (360 $\mathrm{g}$ a.i. ha ${ }^{-1}$ ) (Clincher ${ }^{\circledR}$ ) and a control, without herbicide application. The evaluations of control showed that the biotype ECH 141 had plant that survived in all treatments. This result led to the conduction of a dose response experiment.

The experimental units consisted of plastic pots with capacity of $8 \mathrm{dm}^{3}$. The soil used as a substrate had a sandy texture, which was collected from the subsurface of a nonagricultural field, to ensure that the substrate was free from weed seeds. After collection, the soil was shadow dried and sieved to remove crop residues, clods and coarse materials.

Soil fertilization was performed as described for paddy rice, grown in pregerminated system, for low fertility areas, according to the recommendations Knoblauch et al. (2011).

The experimental design was completely randomized, in a $4 \times 7$ factorial arrangement, with four replications. The first factor was the herbicides: cyhalofop-butyl (Clincher ${ }^{\circledR}$ ), penoxsulam $\left(\right.$ Ricer $\left.^{\circledR}\right)$, quinclorac $\left(\right.$ Facet $\left.^{\circledR}\right)$ and propanil $\left(\right.$ Grassaid $\left.^{\circledR}\right)$, and the second factor consisting of seven herbicide rates $(0.0,0.25$, $0.50,1,2,4$ and $8 \mathrm{X}(\mathrm{X}=$ label rate). The registration rates of the herbicides are: cyhalofop-butyl - $315 \mathrm{~g}$ a.i. ha ${ }^{-1}$, penoxulam $36 \mathrm{~g}$ a.i. ha ${ }^{-1}$, quinclorac $-375 \mathrm{~g}$ a.i. $\mathrm{ha}^{-1}$ and propanil $-2,880 \mathrm{~g}$ a.i. ha-1 .

The adjuvant Veget'Oil ${ }^{\circledR}$ was use for the cyhalofop-butyl (1.5 $\left.\mathrm{L} \mathrm{ha}^{-1}\right)$ and penoxsulam $\left(1.0 \mathrm{~L} \mathrm{ha}^{-1}\right)$ and Assist $^{\circledR}\left(1.0 \mathrm{~L} \mathrm{~h}^{-1}\right)$ was use for quinclorac. Adjuvant was not used for propanil application.

Barnyardgrass seeds (100 seeds per pot) were planted on December 4, 2014. The amount of seeds used was defined according to the seed availability of the biotype
ECH 141. A high density was used due to the heterogeneity of the biotype ECH 141 and the low initial frequency of resistant individuals observed in the preliminary experiment.

The application of the herbicides was performed in December 15, 2014, with seedlings at the stage of 1 to 2 leaves and an average density of 74 (ECH 18) and 47 (ECH 141) plants per pot. The density difference between the two biotypes were due to their different germination index. One day after the application, the pots were flooded with $4-5 \mathrm{~cm}$ of water depth and maintained through the end of the experiment.

The herbicide spray was performed with a $\mathrm{CO}_{2}$-pressurized backpack sprayer, equipped with a spray boom with four flat-fan nozzles (Mod. 110.015), spaced $0.50 \mathrm{~m}$, a constant pressure of $220 \mathrm{kPa}$ psi and a speed of $1.0 \mathrm{~m} \mathrm{~s}^{-1}$, which resulted in an application rate of $150 \mathrm{~L} \mathrm{ha}^{-1}$. The weather conditions during application were air temperature of $27.1^{\circ} \mathrm{C}$, air humidity of $64 \%$ and average wind speed of $3.0 \mathrm{~km} \mathrm{~h}^{-1}$.

Evaluations of percentage of control, plant density per pot and dry mass of shoots were performed 35 days after treatment application. The percentage of control was performed by visual assessments using a percentage scale, in which zero means no control and 100\% death of the plant (SBCPD, 1995).

After counting the number of plants per pot, the results were converted to percentage of plants compared to the control.

The dry mass of the plants was verified by collecting shoots and roots of the plants that survived the treatments and drying at temperature of $60{ }^{\circ} \mathrm{C}$ to a constant mass and measuring the dry mass in a precise digital scale.

The data were submitted to analysis of variance $(p<0.05)$ and, when significant, a non-linear regression model was used, relating the plant response to the herbicide dose used. The three-parameter logistic model was used, as follows:

$$
y=\frac{a}{1+\left(\frac{x}{x_{0}}\right)^{b}}
$$

Planta Daninha, Viçosa-MG, v. 34, n. 4, p. 823-832, 2016 
where $y$ is the dependent variable, $x$ is the independent variable and $a, b$ and $x O$ are the parameters of the logistic model.

The regression model enabled to estimate the rate for controlling $50 \%$ and $80 \%$ of the barnyardgrass $\left(\mathrm{C}_{50}\right.$ and $\left.\mathrm{C}_{80}\right)$ and the rate for reducing $50 \%$ and $80 \%$ of its biomass $\left(\mathrm{GR}_{50}\right.$ and $\left.\mathrm{GR}_{80}\right)$.

The resistance factor $(\mathrm{RF})$ was calculated by dividing the $\mathrm{C}_{50}$ of the resistant biotype by the $\mathrm{C}_{50}$ of the susceptible biotype (Vidal et al., 2006). The resistance was confirmed when $R F>1.0$ (Saari et al., 1994) and the $\mathrm{C}_{80}$ was higher than the herbicide maximum recommended rate (Christoffoleti et al., 2009).

\section{RESULTS AND DISCUSSION}

The barnyardgrass biotype ECH 18 was sensitive to all herbicides evaluated, since it was efficiently controlled $(>90 \%)$ even at the lower rates (Figure 1). However, the ECH 141 biotype was efficiently controlled up to the registration rate only by propanil (PSII inhibitor).

The herbicide cyhalofop-butyl reached the minimum acceptable level of control $\left(\mathrm{C}_{80}\right)$ with a rate $60 \%$ higher than the label recommended rate (Table 1), while the herbicides penoxsulam and quinclorac did not achieve $80 \%$ control at the evaluated rates (0- to $8 \mathrm{x})$. These results confirmed the initial hypothesis that the biotype 141 is multiple resistant to three different mechanism of action (ACCase, ALS inhibitors and synthetic auxins). Two important criteria for resistance confirmation have been met in this study: 1) the resistance factor was higher than 1.0; and 2) the percentage of control of ECH 141 was not adequate using the label rate.

The biotype $\mathrm{ECH} 18$ reduced dry matter accumulation with increasing rate of the herbicides cyhalofop-butyl, penoxsulam, quinclorac and propanil (Figure 2), which reduced the dry mass close to zero with rates lower than 0.5 the label rate. The biotype $\mathrm{ECH} 141$ presented varied response depending on the herbicide used. There was less interference in the dry matter accumulation with penoxsulam and quinclorac. High reduction in shoot biomass was observed with the application of $2 \mathrm{x}$ rates of cyhalofop-butyl label rate $\left(630 \mathrm{~g}\right.$ a.i. $\left.\mathrm{ha}^{-1}\right)$. The application of propanil had similar performance for the two biotypes. In general, the results of dry mass and control were similar for both biotypes.

The susceptible biotype (ECH 18) presented $\mathrm{GR}_{80}$ values lower than the label rate for all herbicides (Table 1). Similar results occurred with application of cyhalofop-butyl and propanil in biotype ECH 141.

There was significant reduction in dry matter accumulation with cyhalofop application in the ECH 141 biotype despite the unsatisfactory control, which may be justified by the fact that not all plants survived the herbicide application (Figure 3). However, the surviving plants development was similar to the control. Regarding the penoxsulam and quinclorac herbicides, $\mathrm{GR}_{80}$ were much higher than the label rates.

According to Huan et al. (2013), the E. crus-galli resistance to ACCase inhibitors (quizalofop-ethyl) is due to a change in sensitivity of the chloroplast enzyme ACCase, and the gene amplification had an important role in this species.

There was no significant reduction in plant density of biotype ECH 141 treated with quinclorac (Figure 3C). The other herbicides reduced plant density with increasing herbicide rates regardless of the biotype evaluated (Figure 3). These results indicate that the frequency of resistant plants of the biotype ECH 141 was low, and that the minority of the population survived penoxsulam and cyhalofop-butyl applications.

According to Silva et al. (2007), the initial frequency of resistant plants in a population can be very low, however, a gradual increase in the frequency of these plants occurs when the selection pressure persists, with a population of about $30 \%$ in seven years. Matzenbacher et al. (2015) evaluated 624 populations of E. crus-galli in southern Brazil and found frequency of plants with resistance to imidazolinones of 0.81 , and to quinclorac of 0.19 . These authors also reported that barnyardgrass resistance is due to its multiple resistance mechanisms and multiple mutations in the ALS enzyme gene, however, 


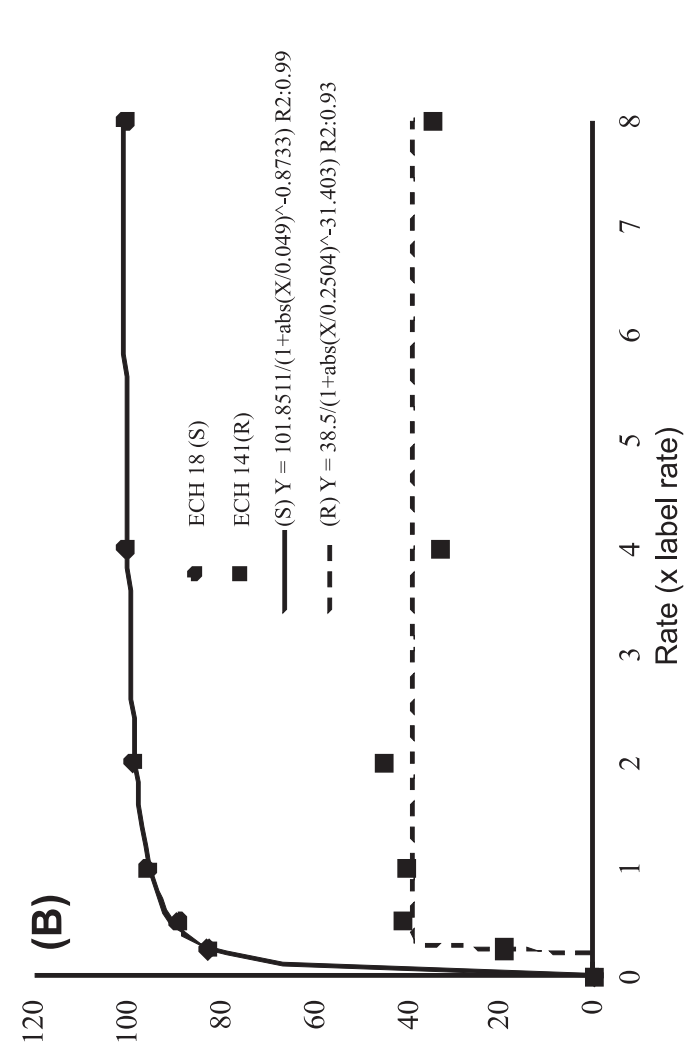

(\%) |одио०

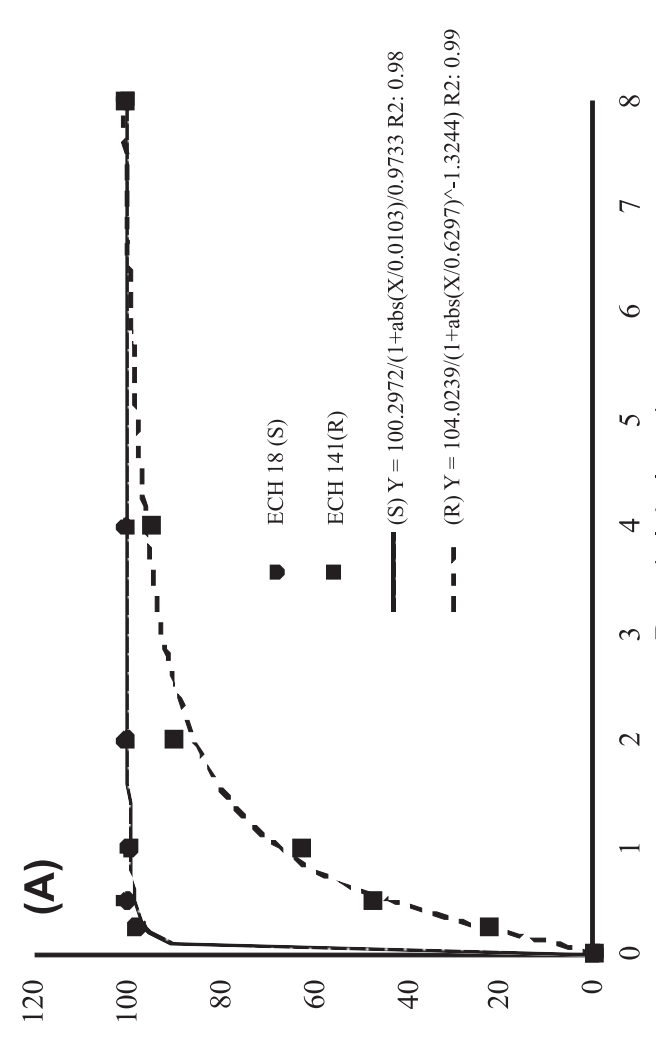

(\%) ןодио०

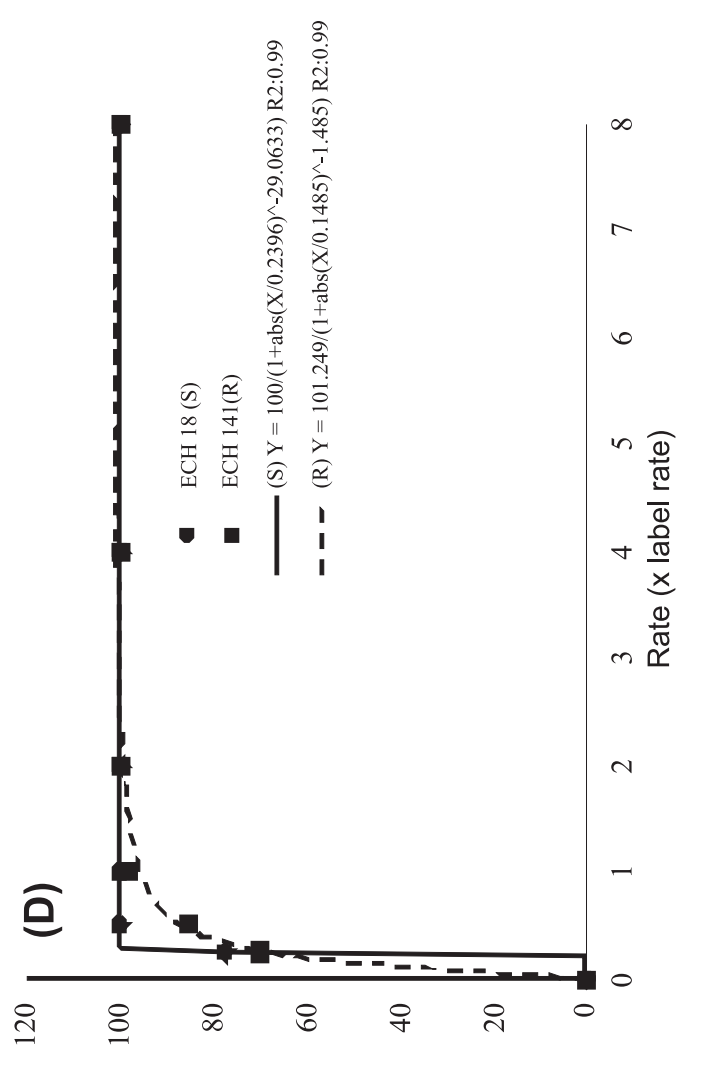

(\%) ןодұoo

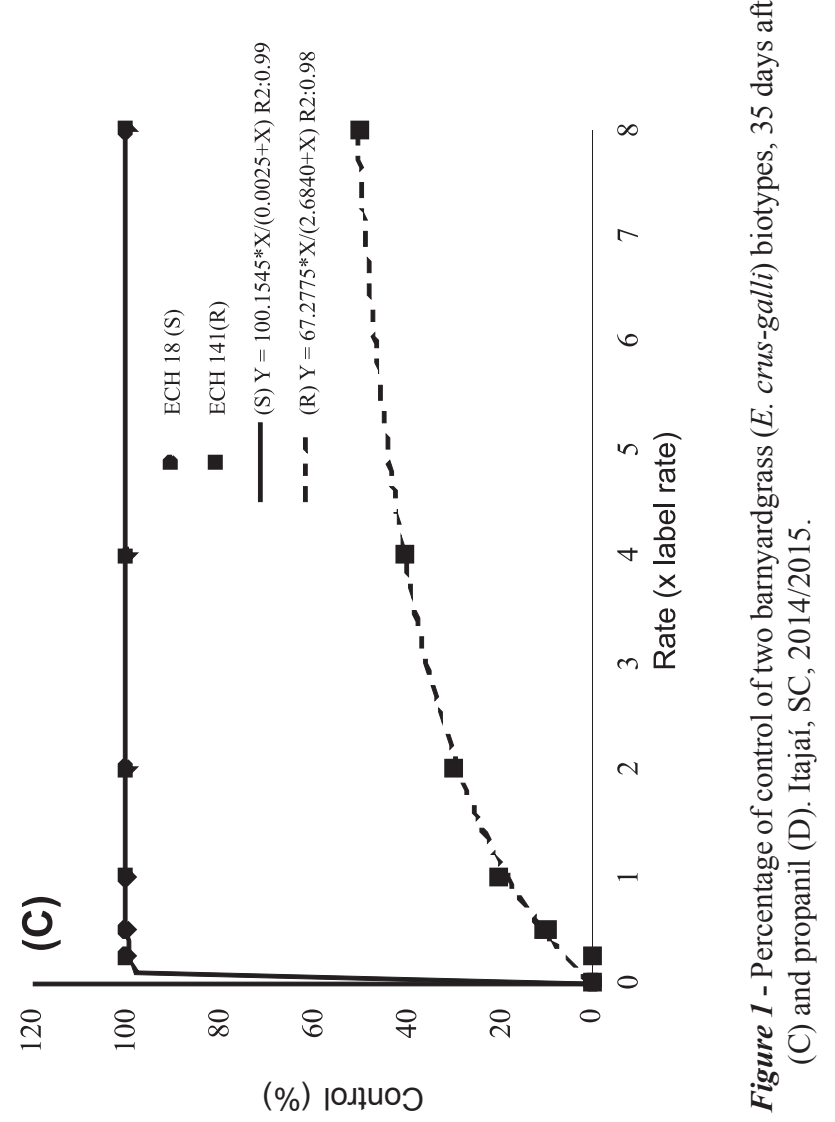


Table 1 - Estimated rate $\left(\mathrm{g} \mathrm{ha}^{-1}\right)$ to provide control of $50 \%$ and $80 \%\left(\mathrm{C}_{50}\right.$ and $\left.\mathrm{C}_{80}\right)$, estimated rate to reduce dry matter accumulation by 50 and $80 \%\left(\mathrm{GR}_{50}\right.$ and $\left.\mathrm{GR}_{80}\right)$ and resistance factor $(\mathrm{RF})$ of two biotypes of barnyardgrass. Itajaí, SC, 2014/2015

\begin{tabular}{|c|c|c|c|c|c|r|r|r|}
\hline \multirow{2}{*}{ Variable } & \multicolumn{2}{|c|}{ Cyhalofop } & \multicolumn{2}{c|}{ Penoxsulam } & \multicolumn{2}{c|}{ Quinclorac } & \multicolumn{2}{c|}{ Propanil } \\
\cline { 2 - 9 } & $\mathrm{S}$ & $\mathrm{R}$ & $\mathrm{S}$ & $\mathrm{R}$ & $\mathrm{S}$ & $\mathrm{R}$ & $\mathrm{S}$ & $\mathrm{R}$ \\
\hline $\mathrm{C}_{50}$ & 3.2 & 198.0 & 1.8 & $-\frac{1}{1}$ & 0.9 & 2925 & 691.2 & 427.7 \\
\hline $\mathrm{C}_{80}$ & 12.6 & 504.0 & 7.9 & - & 3.7 & - & 724.3 & 1045.4 \\
\hline $\mathrm{GR}_{50}$ & 1.6 & 145.8 & 0.14 & $<0.01$ & 2.6 & 555.6 & 73.2 & 114 \\
\hline $\mathrm{GR}_{80}$ & 6.0 & 220.0 & 0.6 & $>288$ & 9.2 & 1541.3 & 288 & 316.8 \\
\hline $\mathrm{RF}$ & 1.0 & 61.9 & 1.0 & - & 1.0 & 3250 & 1.0 & 0.6 \\
\hline
\end{tabular}

Maximum label rate: cyhalofop-butyl $\left(315 \mathrm{~g}\right.$ a.i. $\left.\mathrm{ha}^{-1}\right)$, penoxsulam $\left(50 \mathrm{~g}\right.$ a.i. ha $\left.{ }^{-1}\right)$, quinclorac $\left(375 \mathrm{~g}\right.$ a.i. ha $\left.\mathrm{h}^{-1}\right)$ and propanil $\left(3,600 \mathrm{~g}\right.$ a.i. ha $\left.{ }^{-1}\right)$. $\mathrm{S}=\mathrm{ECH} 18 ; \mathrm{R}=\mathrm{ECH} 141.1 / 2=$ not reached 50 or $80 \%$ of control within the evaluated rates.

they had not found barnyardgrass biotypes resistant to cyhalofop-butyl.

Won et al. (2012) evaluated 155 barnyardgrass accessions from 15 sites in five locations in South Korea and found 25\% of population resistant to ACCase inhibitors, 22\% resistant to ALS inhibitors and $8.2 \%$ with multiple resistance (ACCase + ALS).

The resistance factor $(\mathrm{RF})$ of the biotype $\mathrm{ECH} 141$ for cyhalofop-butyl and quinclorac were high, with values of 61.9 and 3250, respectively (Table 1 ). The $R F$ of the biotype $\mathrm{ECH} 141$ for penoxsulam was not possible to estimate because the control percentage did not reached $50 \%$, even at very high herbicide rates. According to Lopez-Ovejero et al. (2005), high values of RF may be related to the high susceptibility of the known sensitive biotype, which may be one of the factors contributing to the high RF values in this study.

The ECH 141 biotype was sensitive to propanil, presenting an RF of 0.6, i.e., less than 1.0. This result shows that propanil is an effective alternative to control this biotype, and can be used in integrated management systems to contain the resistance evolution in this population. However, propanil must be used in rotation with different mechanism of action, since its repeated use can also select resistant individuals. In the United States there are reports of barnyardgrass biotypes resistant to propanil since 1990 (Malik et al., 2010; Heap, 2015).

These are worrying results, since they present the first case of an Echinochloa population with resistance to three mechanisms of action in Brazil. The
Echinochloa genus had already been confirmed with resistance to quinclorac (Eberhardt et al., 2000; Andres et al., 2007) and to quinclorac and ALS inhibitors (Heap, 2015). In the USA (Mississippi State), there was a reported case of E. crus-galli resistant to fenoxapropp-ethyl, imazamox, imazethapyr, propanil and quinclorac (Heap, 2015), which have distinct mechanism of action. In California, E. phyllopogon biotype was found with resistance to four herbicides (molinate, thiobencarb, fenoxaprop-ethyl and bispyribacsodium), however, this was a sensitive biotype to propanil (Fischer et al., 2000).

The occurrence of multiple resistance in rice fields brings serious consequences for weed management, since limits the number of herbicides and active ingredients available for controlling resistant biotypes, reduce the control efficiency, productivity and rice grains quality, besides the increase in production costs, resulting in reduction of rice production profitability.

This context may lead to modifications on planning the selection of herbicides for weed control. Regarding to barnyardgrass control, high efficiency herbicides such as penoxsulam and cyhalofop-butyl, would be alternatives to propanil, which has a lower efficiency (Ntanos et al., 2000 and Damalas et al., 2008). An alternative would be pre-emergent herbicides, however, their use has restrictions in pregerminated systems (predominant in Santa Catarina) and also may raise the production cost.

According to Fischer et al. (2000), the selection of barnyardgrass biotypes with 


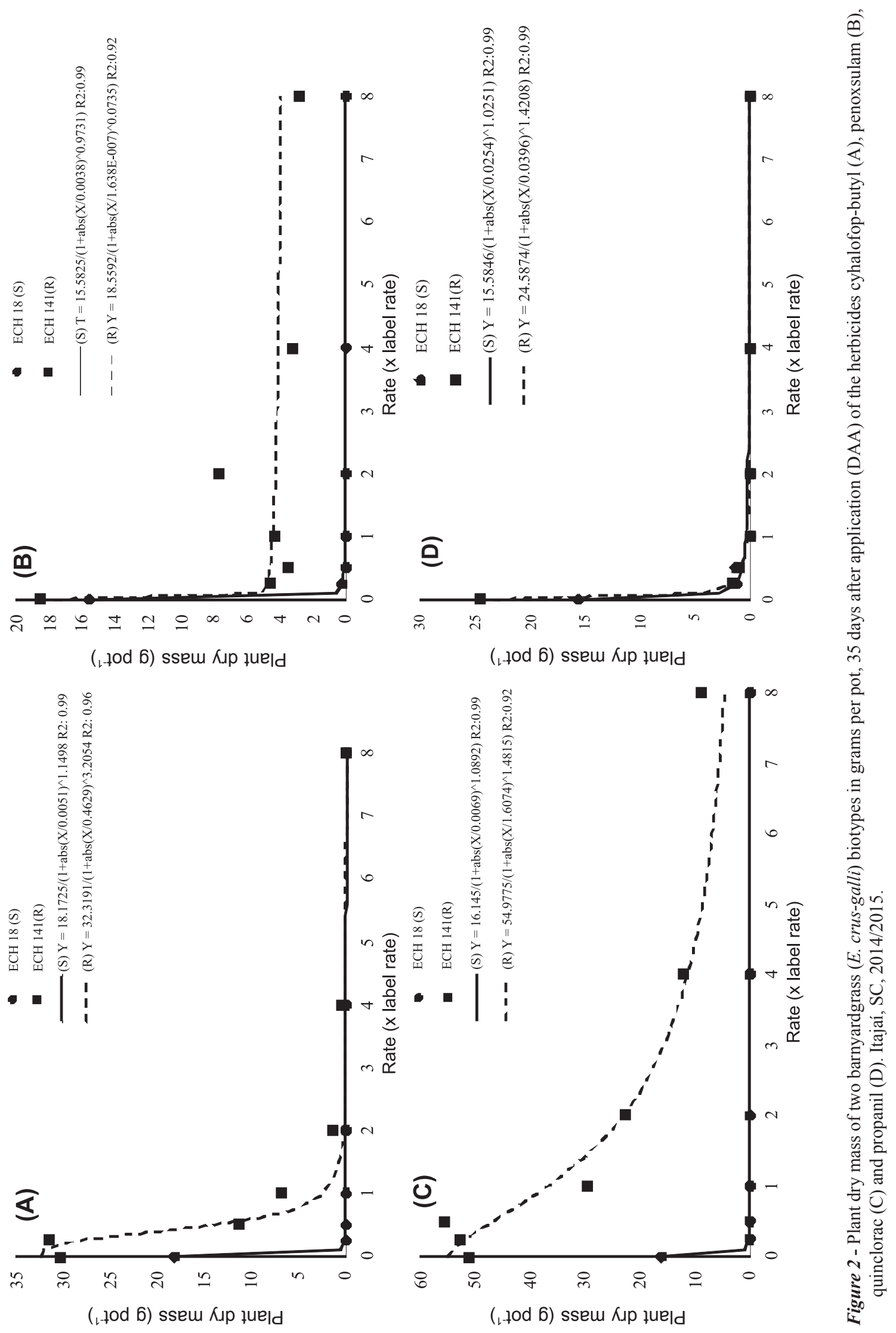



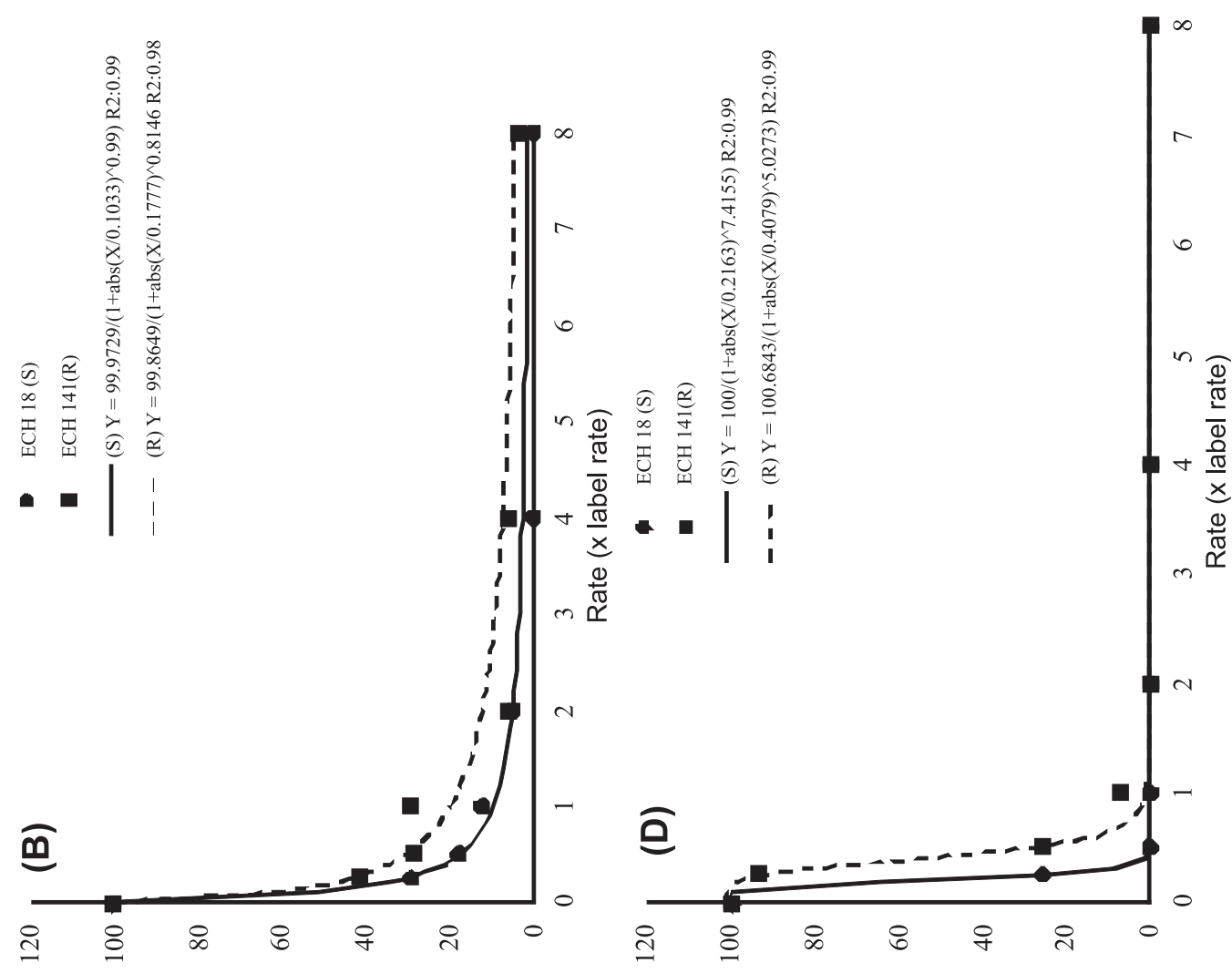

(\%) słuejd jen!ıuns
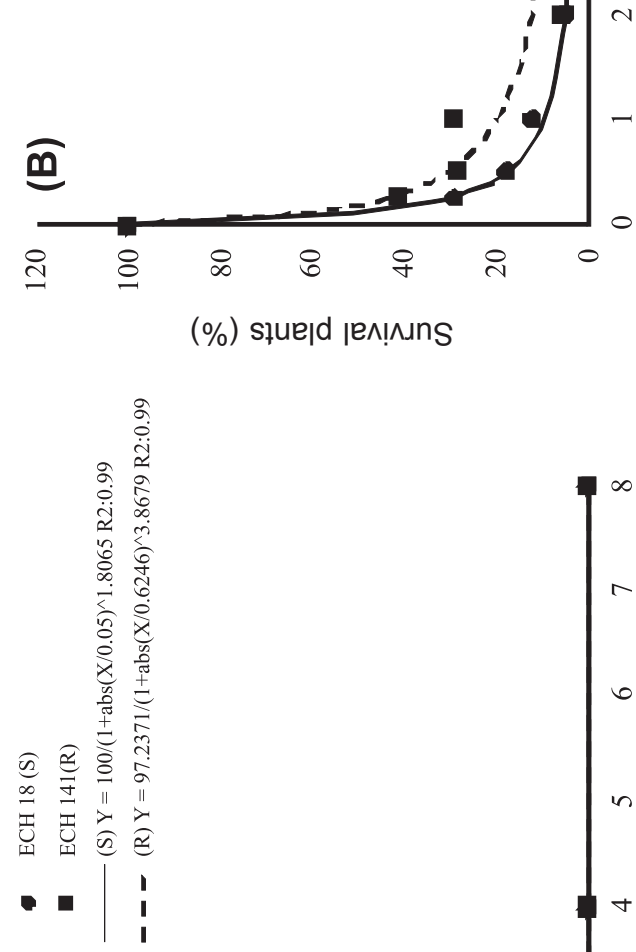

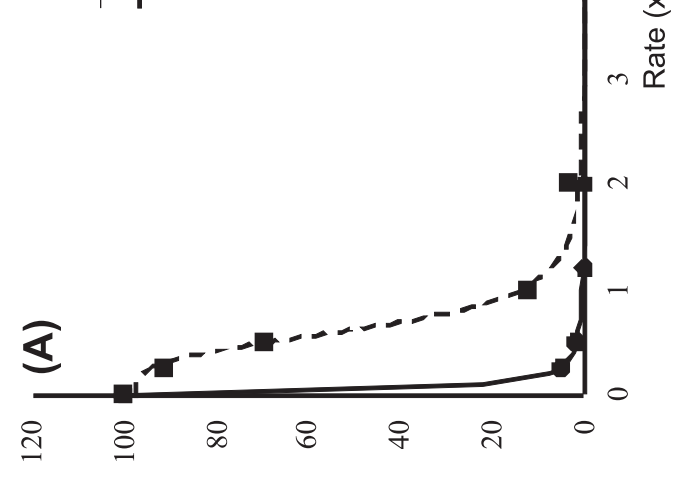

(\%) słuejd jes!ıuns
(\%) słuepd jen!ıuns

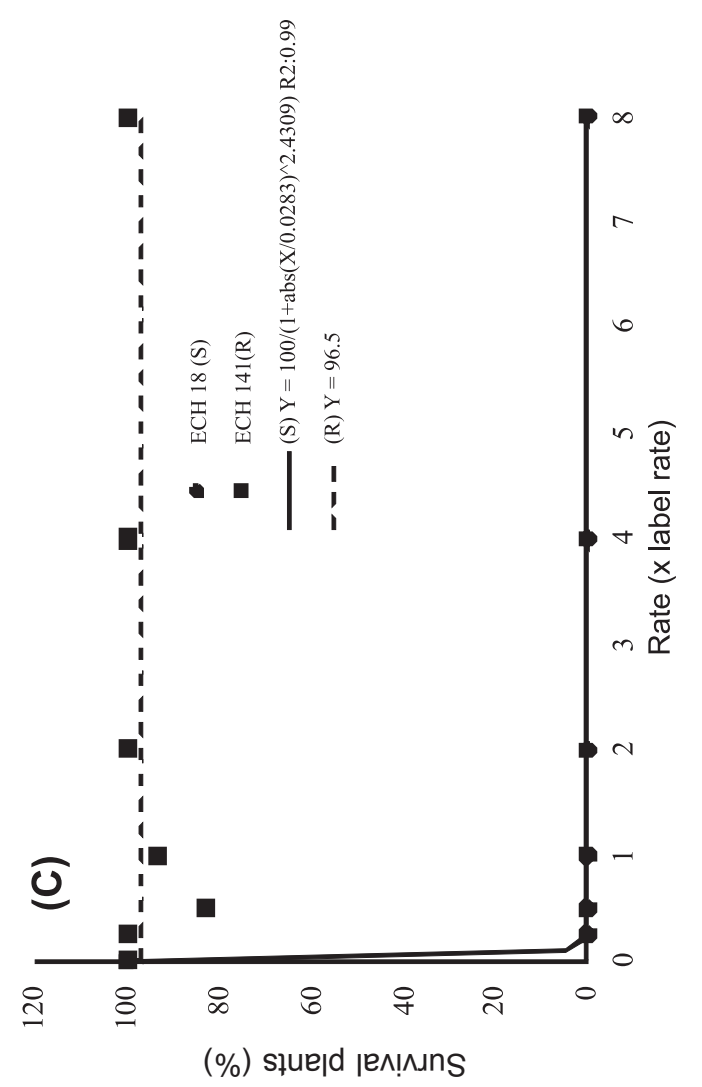


multiple resistances in California (USA) occurred due to repeated application of few different herbicides associated with monoculture. This situation was also registered in areas of irrigated rice in Santa Catarina, Brazil. The use of herbicides integrated with other control measures is essential for controlling multiple herbicide resistant weeds (Fischer et al., 2000; Talbert and Burgos, 2007).

The increasing cases of resistance has narrowed herbicide alternatives for rice production in Santa Catarina and hindering the plant breeding area, especially studies dedicated to develop herbicide-resistant crops, since the occurrence of barnyardgrass biotypes that are resistant to three mechanisms of action may decrease the control efficiency in rice cultivars resistant to imidazolinones (Clearfield Production System).

The initial hypothesis was confirmed, i.e., the ECH 141 biotype presented resistance to herbicides quinclorac (synthetic auxin), penoxsulam (ALS inhibitor) and cyhalofopbutyl (ACCase inhibitor). These findings showed that the control strategies used by rice farmers in Santa Catarina have not been effective to control resistance cases in rice. The integration of control methods is increasingly important in this present situation, with the use of technical recommendations, associating chemical and non-chemical control measures, emphasizing measures that favors the rice crops and not the weeds (cultural control). The ECH 141 biotype was sensitive to the herbicide propanil, which figures as an alternative for integrated weed management systems.

\section{ACKNOWLEDGEMENTS}

The authors thank the Fapesc (Process 6946/2011-9) and the CNPq (Process 562451/ 2010-2) for the financial support for the development of this research.

\section{LITERATURE CITED}

Andres A. et al. Detecção da resistência de capim-arroz (Echinochloa sp.) ao herbicida quinclorac em regiões orizícolas do Sul do Brasil. Planta Daninha. 2007;25:221-6.
Andres A., Machado S.L. O. Plantas daninhas em arroz irrigado. In: GOMES, A. S.; MAGALHÃES JÚNIOR, A. M. Arroz irrigado no Sul do Brasil. Brasília, DF: Embrapa, 2004. p.457-534.

Christoffoleti P.J. Aspectos de resistência de plantas daninhas a herbicidas. 2.ed. Campinas: HRAC-BR, 2004. $120 \mathrm{p}$.

Christoffoleti P.J. et al. Resistência de plantas daninhas aos herbicidas inibidores da EPSPs. In: VELINI, E. D. et al. Glyphosate. Botucatu: FEPAF, 2009. 493p.

Damalas C.A., Dhima K.V., Eleftherohorinos I.G. Morphological and physiological variation among species of the genus Echinochloa in Northern Greece.

Weed Sci.2008;56:416-23.

Eberhardt D.S. et al. Resistência de capim-arroz (Echinochloa crusgalli) ao herbicida quinclorac. In: CONGRESSO BRASILEIRO DA CIÊNCIA DAS PLANTAS DANINHAS, 22., 2000, Foz do Iguaçu. Resumos... Londrina: SBCPD/ Embrapa Clima Temperado, 2000. p.512.

Fischer A.J. et al. Herbicide-resistant Echinochloa oryzoides and E. phyllopogon in California Oryza sativa fields.

Weed Res. 2000;48:225-30.

Gazziero D.L.P., Galli A.J.B., Karam D. Critérios para relatos oficiais estatísticos de biótipos de plantas daninhas resistentes a herbicidas. Sete Lagoas: SBCPD, 2008. 22p.

Heap I.M. International survey of herbicide resistant weeds. Disponível em: www.weedscience.org. Acesso em: 17 abr. 2015.

Huan Z. et al. Determination of ACCase sensitivity and gene expression in quizalofop-ethyl-resistant and susceptible barnyardgrass (Echinochloa crus-galli) biotypes. Weed Sci. 2013;61:537-42.

Inoue M.H., Oliveira Jr. R.S. Mecanismo de ação de herbicidas. In: Oliveira Jr. R.S., Constantin J., Inoue M.H. Biologia e manejo de plantas daninhas. Curitiba: Ominipax. 2011. p.193-214.

Kissmann K.G., Groth D. Plantas infestantes e nocivas. 2.ed. São Paulo: BASF, 1997. Tomo I. 825p.

Knoblauch R., Eberhardy D.S., Bacha R.E. Preparo do solo, adubação e manejo da água. In: Eberhardt D.S. Schiocchet M.A. Recomendações para a produção de arroz irrigado em Santa Catarina (Sistema pré germinado).

Florianopolis: Epagri, 2011. p.17-26.

López-Ovejero R.F. et al. Resistência de populações de capim colchão (Digitaria ciliaris) aos herbicidas inibidores da Acetil Co-A carboxilase. Planta Daninha. 2005;23:543-49. 
Malik M.S., Burgos N.R., Talbert, R.E. Confirmation and control of propanil-resistant and quinclorac-resistant barnyardgrass (Echinochloa crus-galli) in rice.

Weed Technol. 2010;24:226-33.

Matzenbacher F.O. et al. Distribution and analysis of the mechanisms of resistance of barnyardgrass (Echinochloa crusgalli) to imidazolinone and quinclorac herbicides. J Agric Sci. 2015;153:1-15.

Ntanos D.A., Koutroubas S.D., Mavrotas C. Barnyardgrass (Echinocloa crus-galli) control in water-seeded rice (Oryza sativa) with cyhalofop-butyl. Weed Technol. 2000;14:383-8.

Roman E.S. et al. Como funcionam os herbicidas: da aplicação a biologia. Passo Fundo: Berthier, 2007. 160p.

Saari L.L.; Cotterman J.C., Thill D.C. Resistance to acetolactate synthase inhibiting herbicides. In: Powles S.B., Holtum J.A.M. Herbicide resistance in plants: biology and biochemistry. Boca Raton: CRC Press, 1994. p.83-139.
Silva A.A., Vargas L., Ferreira E.A. Herbicidas: resistência de plantas. In: Silva A.A., Silva J.F. Tópicos em manejo de plantas daninhas. Viçosa, MG: Universidade Federal de Viçosa, 2006. p.279-324.

SOCIEDADE BRASILEIRA DA CIÊNCIA DAS PLANTAS DANINHAS - SBCPD. Procedimentos para instalação, avaliação e análise de experimentos com herbicidas. Londrina: 1995. 42p.

Talbert R.E., Burgos N.R. History and management of herbicide resistant barnyardgrass (Echinochloa crus-galli) in Arkansas rice. Weed Technol. 2007;21:324-31.

Vidal R.A. et al. Resistência de Eleusine indica aos inibidores de ACCase. Planta Daninha. 2006;24:163-71.

Won O.J. et al. Identification of herbicide-resistant barnyaedgrass (Echinochloa crus-galli var. crus-galli) biotypes in Korea. Weed Turfgrass Sci. 2012;3:110-13. 